\title{
PENGEMBANGAN SELANCAR (SURFING) MELALUI PEMBERDAYAAN MASYARAKAT (COMMUNITY BASED DEVELOPMENT) DI KAWASAN WISATA PANTAI KUTA, KABUPATEN BADUNG
}

\author{
${ }^{1} \mathrm{~N}$. L. Henny Andayani, ${ }^{2} \mathrm{Ni}$ Nyoman Yulianthini \\ Jurusan D3 Perhotelan, ${ }^{2}$ Jurusan Manajemen Fakultas Ekonomi dan Bisnis \\ Universitas Pendidikan Ganesha \\ Singaraja, Indonesia
}

e-mail: henny.andayani@yahoo.com,yulianthini_nyoman@yahoo.com

\begin{abstract}
Abstrak
Kuta merupakan salah satu kawasan wisata di Kabupaten Badung yang dilengkapi dengan beragam fasilitas wisata, seperti restoran, bar, hotel, laundry, dan money changer. Keberadaan kawasan wisata Kuta tidak terlepas dari atraksi wisata utama berupa keindahan pantai dengan pasir putihnya. Beragam aktifitas wisata seperti berjemur, dan surfing, dapat dilakukan di Kuta. Penelitian ini bertujuan untuk (1) Mengetahui keterlibatan dan peran serta masyarakat local dalam pengembangan potensi wisata selancar (surfing) selama ini (2) Mengetahui strategi pengembangan aktifitas wisata selancar (surfing) sebagai daya tarik wisata baharí/tirta di Bali dengan memberdayakan masyarakat lokal. Pendekatan yang dilakukan dalam penelitian ini adalah pendekatan kualitatif dengan menggunakan teknik pengumpulan data, wawancara, observasi dan studi dokumentasi. Data yang diperoleh selanjutnya dianalisis dengan matriks internal eksternal dan dilanjutkan dengan analisis SWOT. Hasil penelitian menunjukkan bahwa peran serta dan keikutsertaan masyarakat lokal dalam pengembangan selancar (surfing) di kawasan wisata Kuta masih sedikit. Para pelaku dan investor mayoritas berasal dari luar wilayah Kuta. Berdasarkan analisis SWOT didapatkan strategi alternatif yang perlu dikembangkan di Kuta, antara lain: pengembangan surfing berbasis masyarakat lokal di kawasan Kuta, pengembangan usaha jasa pelayanan surfing yang dimiliki dan dikelola oleh masyarakat lokal, strategi peningkatan keamanan dan kenyamanan bagi wisatawan yang melakukan kegiatan surfing di Kawasan Kuta, dan strategi pengembangan kelembagaan terhadap kegiatan surfing.
\end{abstract}

Kata Kunci: strategi, pengembangan, surfing, pemberdayaan masyarakat

\begin{abstract}
Kuta is one of the tourist area in Badung regency which is equipped with various tourist facilities, such as restaurants, bars, hotels, laundry, and money changer . The existence of the tourist area of Kuta can not be separated from the main tourist attractions such as beautiful beaches with white sand. Various activities like sunbathing, and surfing, to do in Kuta. This study aims to (1) Knowing involvement and participation of local communities in the development potential of surfing (surfing) for this (2) Determine the strategy development activities surfing
\end{abstract}


(surfing) as a tourist attraction nautical/Tirta Bali by empowering local communities. The approach taken in this study is a qualitative approach using the techniques of data collection, interviews, observation and documentation studies. The data were then analyzed with the external and internal matrix followed by a SWOT analysis. The results showed that the participation and involvement of local communities in the development of surfing (surf) in the tourist area of Kuta is still small. The actors and the majority of investors are from outside the area of Kuta. Based on the SWOT analysis obtained alternative strategies need to be developed in Kuta, among others: the development of local community -based surf in Kuta, surfingbusiness development services that are owned and managed by local communities, strategies for improving the safety and convenience for travelers who do surf activities in the Area Kuta, and institutional development strategy of the surfing activities.

Key Word: Strategy, development, surfing, community based development

\section{PENDAHULUAN}

Kabupaten Badung merupakan salah satu daerah pariwisata yang berkembang cukup baik dibandingkan daerah lainnya di Bali. Beragam daya tarik wisata yang ditemui di Kabupaten Badung tidak terlepas dari daya tarik alam pantai yang dimiliki. Salah satu obyek daya tarik wisata alam pantai yang ada di Kabupaten Badung adalah Pantai Kuta.

Pantai Kuta terkenal sebagai salah satu destinasi pariwisata di dunia karena keindahan pantainya. Daya tarik Kuta berupa pantai dengan lengkung pantai yang berupa bulan sabit dengan hamparan pasir putih, serta keindahan matahari terbenam (sunset) dengan beragam aktifitas wisata, seperti melihat matahari terbenam (sunset), berjemur (sun bathing), berenang (swimming), berselancar ataupun sekedar menikmati fasilitas yang ada seperti bungy jumping dan water boom. Disamping menawarkan beragam aktifitas, Pantai Kuta juga dilengkapi beragam fasilitas berupa sarana dan prasarana pariwisata, seperti tourist information centre, money changer, shopping centre, serta beragam hotel dan restoran.

Kegiatan selancar (surfing) dewasa ini banyak dilakukan oleh wisatawan di Kuta. Potensi ombak yang dimiliki Pantai Kuta menjadi sebuah daya tarik bagi wisatawan, khususnya bagi peselancar. Hal ini disebabkan oleh tantangan yang ditawarkan Pantai Kuta berbeda dengan pantai lainnya di Bali, dimana ombak di Pantai Kuta bisa ditemukan setiap hari dan sangat beragam, mulai dari ombak kecil yang diperuntukkan bagi pemula, sampai dengan ombak besar yang diperuntukan bagi para peselancar profesional. Selain itu Pantai Kuta juga sering digunakan sebagai tempat untuk penyelenggaraan perlombaan selancar baik tingkat nasional maupun dunia (www.traveloi.com).

Berkembang pesatnya aktifitas selancar (surfing) di Pantai Kuta hingga saat ini belum memberdayakan masyarakatnya, dimana para pelaku peselancar (surfer) mayoritas merupakan pendatang dari luar daerah. Minimnya keterlibatan masyarakat local dalam kegiatan pengembangan aktifitas selancar (surfing) memberikan dampak

Jurnal IImu Sosial dan Humaniora | 352 
negative terhadap manfaat ekonomi yang diterima. Tidak terdistribusinya secara merata manfaat dari pengembangan kepariwisataan dapat memicu munculnya kesenjangan social antara masyarakat local dan masyarakat pendatang. Untuk itu diperlukan adanya pola pengembangan yang tepat terhadap aktifitas wisata selancar (surfing) yang ada di Kawasan Pantai Kuta sehingga pengembangan kepariwisataan mampu memberdayakan masyarakat lokal dan benar-benar dapat memberikan manfaat secara langsung kepada masyarakatnya.

\section{METODE}

Jenis penelitian ini merupakan penelitian kualitatif yang dilakukan dengan teknik pengumpulan data melalui observasi (pengamatan langsung di obyek penelitian), wawancara mendalam terhadap informan yang telah ditetapkan, dan studi dokumentasi. Penelitian ini dilakukan di kawasan wisata kuta, kabupaten Badung. Data penelitian ini akan dianalisis secara deskriptif kualitatif dan disajikan dalam bentuk naratif. Adapun Teknik analisis data yang digunakan dalam penelitian ini antara lain: 1) Metode Deskriptif Kualitatif dan 2) Analisis SWOT untuk menghasilkan beberapa strategi umum (Grand Strategy) pengembangan potensi wisata selancar (surfing) di Kawasan Wisata Pantai Kuta.

\section{HASIL DAN PEMBAHASAN}

Kuta yang merupakan bagian dari Kabupaten Badung, memiliki daya tarik keindahan pantainya. Secara administratif, wilayah Kecamatan Kuta dibagi menjadi 5 Kelurahan, yaitu Kelurahan Kedonganan, Kelurahan Tuban, Kelurahan Kuta, Kelurahan Legian, dan Kelurahan Seminyak.

Adanya peningkatan kunjungan wisatawan ke Kabupaten Badung, memberikan kesempatan bagi investor untuk menanamkan modalnya dengan membuka beragam jenis usaha. Beragam jenis usaha ini ada dan berkembang bertujuan untuk memenuhi kebutuhan wisatawan. Keberadaan beragam fasilitas wisata dapat dilihat pada tabel 1 dan tabel 2 di bawah.

Tabel 1 Jumlah Akomodasi Wisata di Kabupaten Badung

\begin{tabular}{|cccc|}
\hline Tahun & Hotel Berbintang & Hotel Melati & Pondok Wisata \\
\hline 2007 & 94 & 379 & 239 \\
2008 & 96 & 472 & 325 \\
2009 & 98 & 505 & 395 \\
2010 & 98 & 541 & 475 \\
2011 & 98 & 596 & 599 \\
\hline
\end{tabular}

Sumber Dinas Pariwisata Badung 
Tabel 2 Banyaknya Hotel Bintang dan Melati di Kecamatan Kuta

\begin{tabular}{|c|c|c|c|c|c|c|}
\hline \multirow{2}{*}{ Kelurahan } & \multicolumn{7}{|c|}{ Hotel Berbintang } & \multirow{2}{*}{ Hotel Melati } \\
\cline { 2 - 6 } & $\mathbf{1}$ & $\mathbf{2}$ & $\mathbf{3}$ & $\mathbf{4}$ & $\mathbf{5}$ & \\
\hline Kedonganan & - & - & 3 & - & - & 8 \\
\hline Tuban & - & - & 1 & - & 1 & 10 \\
\hline Kuta & 1 & 6 & 8 & 8 & 5 & 105 \\
\hline Legian & 1 & 19 & 9 & 3 & 6 & 104 \\
\hline Seminyak & - & 1 & 1 & 4 & 4 & 31 \\
\hline & & & & & & \\
\hline 2010 & 2 & 26 & 22 & 15 & 16 & 258 \\
\hline 2009 & 2 & 11 & 19 & 15 & 8 & 257 \\
\hline 2008 & 1 & 11 & 16 & 15 & 8 & 267 \\
\hline & & & & & & \\
\hline
\end{tabular}

Sumber: Kuta Dalam Angka 2011

Berdasarkan keberadaan Kecamatan bahwa investor baik asing maupun lokal masih mempercayakan daerah-daerah di Kabupaten Badung, salah satunya Kuta sebagai tempat untuk menanamkan modal usahanya dalam bisnis kepariwisataan.

Kepariwisataan Pantai Kuta semakin berkembang dengan munculnya aktifitas wisata selancar (surfing). Aktifitas Selancar (surfing) sangat digemari oleh wisatawan yang berkunjung ke Pantai Kuta, berdasarkan hasil wawancara di lapangan sebagian besar wisatawan datang ke pantai kuta untuk menikmati keindahan pantai kuta tertarik untuk mencoba bermain selancar (surfing). Dari 20 orang wisatawan yang diwawancarai, para peselancar ini datang dari berbagai negara, dan mayoritas dilakoni oleh wisatawan asal australia, yang dapat dilihat pada tabel 3 berikut:

Tabel 3 Wisatawan yang Melakukan Kegiatan Selancar (Surfing)

\begin{tabular}{|c|c|c|}
\hline NO & WISATAWAN & VOLUME \\
\hline 1 & Australia & 5 \\
\hline 2 & Jepang & 4 \\
\hline 3 & Rusia & 1 \\
\hline 4 & Amerika & 20 \\
\hline
\end{tabular}

Sumber: Penelitian di Lapangan 2012 
Keberadaan selancar (surfing) di Pantai Kuta saat ini, mampu memberikan kontribusi positif terhadap masyarakatnya, khususnya untuk memenuhi kebutuhan wisatawan dalam melakukan kegiatan selancar (surfing). Lapangan pekerjaan baru mulai terbuka, seperti menyewakan papan selancar, menjadi tutor selancar, membuka sekolah selancar bagi pemula, dll.

Perkembangan usaha selancar saat ini cukup pesat dan tersebar di sepanjang pesisir pantai. Peminat untuk kegiatan surfing juga banyak dan berasal dari berbagai kalangan. Peluang usaha ini begitu menjanjikan bagi masyarakat lokal, karena saat ini harga yang dikenakan bagi peserta pemula minimum $\$ 32$ bagi wisatawan asing dan Rp 150.00 bagi wisatawan domestik untuk belajar surfing selama 3 jam. Peluang usaha ini belum mendapat perhatian yang cukup serius dari masyarakat lokal. Justru peluang ini benar-benar dimanfaatkan oleh masyarakat pendatang baik itu berstatus pengusaha, dan tutornya, sedangkan masyarakat Kuta cenderung memilih untuk membuka usaha penginapan, kos-kosan, dan membuka art shop dibandingkan ikut serta dalam pengembangan kegiatan selancar (surfing).

Masyarakat

lokal keikutsertaannya dalam pengembangan kegiatan surfing sejauh ini masih minim, hal ini terbukti dengan mayoritas tutor di kegiatan selancar (surfing) dilakoni oleh masyarakat luar baik yang berasal dari luar Bali dan Kuta, seperti: medan, buleleng, jawa dan daerah lainnya. Para tutor mayoritas yang bergelut di bidang selancar (surfing) belajar surfing secara otodidak di Pantai Kuta bukan belajar melalui pendikan baik formal maupun informal. Adapun tak lain bertujuan untuk mencari penghidupan yang layak dengan mendapatkan sedikit rejeki dari limpahan mata uang asing yang tersebar di Kuta. Masyarakat kuta sejauh ini cenderung melirik usaha koskosan, penginapan dan membuka art shop untuk mengais rezeki berupa mata uang asing.

Kondisi ini cukup memprihatinkan melihat perkembangan aktifitas selancar (surfing) di Pantai Kuta yang sangat pesat dewasa ini. Bagi wisatawan yang berkunjung ke Kuta merasa tidak lengkap rasanya jika belum mencoba aktifitas selancar (surfing) dengan menaklukkan ombak pantai kuta. Disamping itu perkembangan selancar (surfing) di Pantai Kuta juga membuka peluang usaha baru bagi masyarakatnya seperti menjadi tutor selancar (surfing), membuka usaha penyewaan dan jual beli papan selancar (surfing boards), membuka usaha sekolah selancar (surfing school), dan usaha lainnya. Kondisi ini juga jika benar-benar dimanfaatkan masyarakat lokal dapat membuka peluang usaha baru dalam rangka mendiversifikasikan peluang usaha yang telah berkembang saat ini di Pantai Kuta.

Keikutsertaan masyarakat lokal dalam kegiatan selancar (surfing) baru dilakoni oleh kelompok nelayan saja. Keberadaan kelompok nelayan hingga saat ini juga masih eksis karena keberadaan aktifitas selancar (surfing). Keberadaan kelompok nelayan pun sedikit memberikan kontribusi terhadap pengembangan wisata surfing di Kuta. Kaum nelayan sejauh ini keikutsertaannya dalam pengembangan 
kegiatan surfing sebatas mengantarkan wisatawan yang ingin mencoba mencari tantangan berupa ombak yang lebih besa, salah satunya mengantarkan wisatawan ke kuta reef.

Sejalan dengan semakin pesatnya penikmat kegiatan selancar di dunia pada umumnya dan kuta pada khususnya, membuat masyarakat nelayan mulai tergerak untuk ikut serta dalam kegiatan selancar (surfing). Didorong oleh terselenggaranya eventevent selancar (surfing) yang dilaksanakan di pantai kuta pada awalnya dan mulai tersebar di daerah lainnya di Bali dan wilayah Indonesia, menjadi peluang baru bagi para nelayan untuk mengasah bakat dalam menaklukkan ombak. Masyarakat nelayan mencoba mengais rejeki dengan mencoba memenangkan setiap kompetisi selancar (surfing) menjadi sesuatu hal yang wajib dilakukan untuk menjadi atlet selancar dan mencari sponsor.

Jadi saat ini sudah mulai terjadi perubahan dimana pada masa lalu masyarakat nelayan hanya mencari ikan, kini mulai beralih menjadi guide dengan mengantarkan wisatawan penikmat selancar ke spot-spot yang ombaknya mampu memberikan tantangan luar biasa serta menjadi atlet selancar (surfing) yang mewakili Bali atau perusahaan sponsor yang menggaji mereka.

Untuk mengetahui strategi pengambangan surfing, maka dilakukan identifikasi terhadap faktor internal dan eksternal.
A. Identifikasi Faktor Internal
1. Kekuatan

- Kuta merupakan point centre pariwisata Bali

- Ombak pantai kuta yang relatif beragam sehingga dapat dimanfaatkan oleh level pemula sampai dengan level advance

- Masyarakat nelayan ikut serta dalam pengembangan surfing dengan menjadi pemandu wisata bagi wisatawan yang ingin bermain surfing di luar pantai Kuta

- Ketersediaan sarana dan prasarana penunjang pariwisata yang memadai

- Keberadaan surfschool yang dilengkapi dengan para tutor bagi wisatawan pemula yang ingin belajar selancar/ surfing.

- Keberadaan lifeguard yang membuat situasi menjadi lebih aman

- Terdapatnya kelompok nelayan yang dapat dijadikan guide untuk berkunjung ke spot surfing yang lebih menantang

2. Kelemahan

- Belum adanya licensi atau sertifikat untuk kegiatan selancar (surfing) khususnya bagi para tutor sehingga terkesan tidak profesional dalam memberikan tutoring kepada pemula

- Masyarakat local sedikit yang bergelut dengan kegiatan surfing, mayoritas tutor selancar (surfing) digeluti oleh orang luar

- Investor yang bergelut di bidang surfing (surf scholl) sedikit berasal dari masyarakat lokal, mayoritas dikuasai oleh orang asing dan luar bali

- Masyarakat cenderung melakukan investasi dengan membuat 
penginapan, dan kos-kosan karena dianggap lebih menjanjikan

- Masih terdapatnya masyarakat miskin di kecamatan kuta

B. Identifikasi Faktor Eksternal

1. Peluang

- Perkembangan wisata bahari seperti selancar yang sudah mulai mendunia

- Keberadaan event-event untuk aktifitas selancar yang mulai banyak diselenggarakan

- Pertumbuhan ekonomi global terutama pada negara-negara maju maupun negara kawasan asia pasifik

- Pertumbuhan ekonomi nasional

- Kemajuan teknologi, baik teknologi informasi maupun transportasi

- Keamanan Bali yang berangsur mulai pulih..

- Meningkatkan hubungan kerjasama dengan pelaku usaha jasa pariwisata.

2. Ancaman

- Kondisi politik global

- Kondisi alam yang tidak menentu

- Persaingan dengan obyek wisata sejenis

- Kurangnya peran serta masyarakat dalam mengelola atraksi wisata surfing

- Pemberlakuan travel warning oleh beberapa negara

Kombinasi faktor internal dengan faktor eksternal di bawah yaitu :

1. Strategi SO

Strategi yang dihasilkan adalah Strategi pengembangan surfing berbasis masyarakat lokal di kawasan Kuta

\section{Strategi ST}

Strategi yang dihasilkan pengembangan usaha jasa pelayanan surfing yang dimiliki dan dikelola oleh masyarakat lokal

3. Strategi WO

Strategi yang dihasilkan peningkatan keamanan dan kenyamanan bagi wisatawan yang melakukan kegiatan surfing di Kawasan Kuta

4. Strategi WT

Strategi yang dihasilkan pengembangan kelembagaan terhadap kegiatan surfing.

\section{SIMPULAN}

Masyarakat lokal keikut sertaannya dalam pengembangan kegiatan surfing sejauh ini masih minim, hal ini terbukti dengan mayoritas tutor di kegiatan selancar (surfing) dilakoni oleh masyarakat luar baik yang berasal dari luar Bali dan Kuta, seperti: medan, buleleng, jawa dan daerah lainnya. Disamping tutor selancar usaha jasa surf school juga dominan dimiliki oleh investor dari luar kuta.

Keikutsertaan masyarakat lokal dalam kegiatan selancar (surfing) baru dilakoni oleh kelompok nelayan saja. Keberadaan kelompok nelayan hingga saat ini juga masih eksis karena keberadaan aktifitas selancar (surfing). Keikutsertaan nelayan dalam pengembangan kegiatan surfing sebatas mengantarkan wisatawan yang ingin mencoba mencari tantangan berupa ombak yang lebih besa, salah satunya mengantarkan wisatawan ke kuta reef.

Kombinasi faktor internal dengan faktor eksternal di bawah yaitu:

1. Strategi SO

Jurnal IImu Sosial dan Humaniora | 357 
Strategi yang dihasilkan adalah Strategi pengembangan surfing berbasis masyarakat lokal di kawasan Kuta

2. Strategi ST

Strategi yang dihasilkan pengembangan usaha jasa pelayanan surfing yang dimiliki dan dikelola oleh masyarakat lokal

3. Strategi WO

Strategi yang dihasilkan peningkatan keamanan dan kenyamanan bagi wisatawan yang melakukan kegiatan surfing di Kawasan Kuta

4. Strategi WT

Strategi yang dihasilkan pengembangan kelembagaan terhadap kegiatan surfing.

\section{DAFTAR PUSTAKA}

Anonim.2012. "Profil Dinas Pariwisata Kabupaten Badung Tahun 2012". Badung: Dinas Pariwisata Badung.

Anonim. 2012. " Badung dalam Angka 2012". Badung: Badan Pusat Statistik

Anonim. 2011. "Kecamatan Kuta Dalam Angka 2011". Badung: Kecamatan Kuta

Ardika, I Gde. 2000. "Beberapa Pokok Pikiran tentang Pengembangan Wisata Bahari di Bali". Naskah Lengkap Seminar Nasional: Denpasar: Universitas Udayana

Budiharsono, Sugeng.2001. Teknik Analisis Pembangunan Wilayah Pesisir dan Lautan. Jakarta: PT Pradnya Paramitha.

Butler, R. 1992. Alternative tourism: The Thin Edge Of The Wedge. In: V.L.
Smith and W.R. Eadington (eds) Tourism Alternatives: Potentials and Problems in the Development of Tourism. Philadelphia: University of Pennsylvania Press. p. 31-46.

Dahuri, Rokhim,. Rais., Ginting., Sitepu.2001. Pengelolaan Sumber Daya Wilayah Pesisir dan Lautan secara terpadu. Jakarta: PT Gramedia Pustaka Utama.

Dahuri, Rokhim. 2003. Keanekaragaman Hayati laut asset pembangunan berkelanjutan Indonesia. Jakarta: PT Gramedia Pustaka Utama.

Dyana, Tri Arya. 2004. Pemulihan Ekonomi Bali Melalui Penerapan Pariwisata Kerakyatan Sebagai Perwujudan Ekonomi Kerakyatan. Analisis pariwisata no. 1 vol. 6 hal 7-10

France, Lesley. 1997. Sustainable Tourism. UK : Earthscan Publications Limited.

Gunn, Clare A. 1994. Tourism Planning Basics, Concepts, Cases. Third Edition. New York NY 10017, USA: Taylor \& Francis.

Hikmat, Harry. 2001. Strategi Pemberdayaan Masyarakat. Bandung:Humaniora Press.

Inskeep, Edward. 1991. Tourism Planning In Integrated and Sustainable Development Approach, New York: Van Nostrand Reinholhd.

Nadiasa, Mayun, D.N.K Widnyana Maya, I N. Norken. 2010. Analisis Investasi Pengembangan Potensi Pariwisata Pada Pembangunan 
Waduk Jehem di Kabupaten Bangli. Dalam Jurnal IImiah Teknik Sipil Vo. 14, No. 2 Juli 2010.

Nasikun. 1997. Model Pariwisata Pedesaan: Permodelan Pariwisata Pedesaan Untuk Pembangunan Pedesaan Yang Berkelanjutan. Dalam Myra P Gunawan Perencanaan Pariwisata Berkelanjutan. Bandung: Institut Teknologi Bandung.

Natori, Nasahiko. 2001. A Guide Book for Tourism Based Community Development. Osaka Japan: Publiser APTE.

Palguna, A.A. 2001. "Dinamika Masyarakat menuju Civil Society (kasus Pengelolaan Obyek Wisata Alas Kedaton)" (tesis). Denpasar: Program pascasarjana Universitas Udayana.

Palupi, Santi dan Ingkadijaya Rahmat. 2000. Pelatihan bagi masyarakat untuk meningkatkan peran sertanya dalam pembangunan pariwisata pedesaan. Dalam Jurnal IImiah Pariwisata vol. 5 No. 1 Agustus 2000. Hal 13-25. Jakarta : STP Trisakti

Paturusi, Syamsul Alam. "Perencanaan Kawasan Pariwisata". Denpasar: Universitas Udayana

Pendit, S. 1999. Wisata Konvensi, Potensi Gede Bisnis Besar.
Jakarta : PT. Gramedia Pustaka Utama.

Picard, Michael. 2006. Bali: Pariwisata Budaya dan Budaya Pariwisata. Jakarta: Kepustakaan Populer Gramedia

Pitana, I Gde. 1999. Pelangi Pariwisata Bali. Denpasar: Bali Post.

Pitana, I Gde. 2002a. Apresiasi Kritis terhadap Kepariwisataan Bali. Denpasar: The Works

Pitana, I Gde. 2002b. "Pariwisata Wahana Pelestarian Kebudayaan dan Dinamika Masyarakat Bali". Orasi ilmiah dalam pengukuhan guru besar. Denpasar: Universitas Udayana.

Pitana, I Gde dan Gayatri, Putu G. 2005. Sosiologi Pariwisata. Yogyakarta: Andi

Prijono, Onny S. dan A. M. W Pranarka. 1996. Pemberdayaan: Konsep, Kebijakan dan Implementasi. Jakarta: CSIS

Rangkuti, Freddy. 2002. Analisis SWOT teknik membedah Kasus Bisnis. Jakarta: Gramedia Pustaka Utama.

Rata, IB. 2001. "Pengembangan dan Penataan Objek Wisata yang Berorientasi pada Pelestarian Lingkungan dan Pariwisata Budaya”. Denpasar. 